Hanna Kurowska

ORCID: https://orcid.org/0000-0002-8885-6449

University of Zielona Góra, Faculty of Humanities

email: h.kurowska@ih.uz.zgora.pl

\title{
Population of Gubin District in the Context of Situational and Statistical Reports in the Years 1945-1949
}

\section{Ludność powiatu gubińskiego w świetle sprawozdań sytuacyjno-statystycznych z lat 1945-1949}

\begin{abstract}
The article aims to reconstruct the number of inhabitants in the Gubin district in the early post-war years. The statistical data available include previously unused source material in the form of reports and lists of the district administrator and the State Repatriation Office (PUR). The displacement of Germans and the influx of Poles will be discussed, the district's population levels will be given with a division into town and village, and the speed of change in 1945-1949 will be indicated, as well as the population structure in terms of sex, age, nationality and direction of influx (repatriates from the East and West and displaced people from central Poland).
\end{abstract}

\begin{abstract}
Abstrakt
Artykuł ma na celu odtworzenie stanu liczbowego mieszkańców powiatu gubińskiego w pierwszych powojennych latach. Zebrane dane statystyczne obejmują niewykorzystany dotąd szerzej materiał źródłowy w postaci sprawozdań i wykazów starostwa powiatowego oraz PUR. Omówiono wysiedlanie Niemców i napływ ludności polskiej, przedstawiono liczbę ludności powiatu z podziałem na miasto i wieś oraz wskazano dynamikę zmian w latach 1945-1949, a także strukturę ludności pod względem płci, wieku, narodowości i kierunku napływu (repatrianci ze wschodu i zachodu oraz przesiedleńcy z Polski centralnej).
\end{abstract}




\section{Keywords}

Post-war settlement, displacement, migration, population structure, Gubin District, town, rural areas

\section{Słowa kluczowe}

osadnictwo powojenne, wysiedlenia, migracja, struktura ludności, powiat gubiński, miasto, wieś

\section{Introduction}

The population in the early post-war years is particularly hard to determine. World War II changed the world map, and the new state borders had an impact on increased migration in Europe. Gubin District is one of those that were incorporated into Poland in 1945. The indigenous people i.e., people who had lived in German territory before 1939 but had declared their Polish origins, were on the margins of the community. Therefore, to put it simply, we can say that the German population was replaced by Poles, and the very process of rebuilding the population potential turned out to be long and highly unsatisfactory. The speed of population changes makes it very difficult to form an accurate picture of individual districts in the Lubuskie Region. ${ }^{1}$ Monographs on cities and districts usually give publicly available statistical data from the two censuses of 1946 and 1950 and do not go into the dynamics of changes between them. The aim of this article, therefore, is to present the quantitative status of the population in the Gubin district in the early post-war years (to the end of 1949). As of now, the only article to address this issue was written by Henryk Dominiczak almost half a century ago, but for the years 1945-1950 he focused more on political issues and property relations than on demography. ${ }^{2}$

The district in this article consisted of one town, Gubin, and five rural municipalities: Biecz, Czarnowice, Markosice, Pole and Wałowice. The reports used as the source made it possible to show the speed of change in the number of people, the structure of the district's population in terms of place of residence, sex, nationality and origin, and also (partially) the balance of the migratory movement divided into repatriated and displaced people. A statistical and descriptive method will be used.

\footnotetext{
${ }^{1}$ Emphasized by Prof. Czesław Osękowski in his article "Nowi 'Lubuszanie' wobec problemów osadniczych i politycznych na Ziemi Lubuskiej w latach 1945-1956. Opór - przystosowanie - uległość," Studia Paradyskie 28 (2018): 255.

${ }^{2}$ Henryk Dominiczak, "Osadnictwo i stosunki demograficzne w powiecie gubińskim w latach 1945-1960,” in: Gubin, ed. Wiesław Sauter (Zielona Góra: Lubuskie Towarzystwo Kultury, 1971).
} 
The time and space frames of the article stem from the source material preserved. ${ }^{3}$ Monthly descriptive and tabular reports were submitted by the Gubin administrator to the Poznan voivode, while tabular reports were sent by the head of the district branch of the State Repatriation Office (PUR) to the voivodeship office of the PUR in Poznan. ${ }^{4}$ This is therefore the only available, relatively complete statistical material for the years 1945-1949 that allows us to capture the quantitative status of the population in the early post-war years. Unfortunately, the administrator's reporting changed the content, which makes it impossible to analyze it fully. Monthly Lists of Repatriates and Displaced Persons Settled on Former German Farms in Gubin District have been preserved for almost the whole of 1946, ${ }^{5}$ for 1947 there are the Lists of Repatriates and Displaced Persons Settled by the PUR on Post-German Rural Farms and Lists of Repatriates and Displaced Persons in Total Settled in Cities, ${ }^{6}$ while for 1948 and the first half of the following year we have the Situational and Statistical Report. ${ }^{7}$ All these sources are tabular, with some of them classifying the population into repatriates and displaced persons, and although this classification has become established in the literature on the subject, today it is rightly emphasized that it is inappropriate in the context of the situation. ${ }^{8}$ The above terms will be used in the article, as they are imposed by the statistical material used.

These previously unused sources of material are stored in the State Archives in Zielona Góra in the collections Gubin District Office, Gubin, Poznan' Voivodeship Office, Gorzów Branch and in the State Archive in Poznań in the State Repatriation Office, Voivodeship Branch, Poznań collection. The lists are located either in one archival unit (e.g., for a specific year), or they are scattered in different units or even groups, hence the difficulty in completing them. The sources are

${ }^{3}$ Situation reports of administrators from the Lubuskie Region, or on the Polish scale, have been preserved in the archives, but their completion for the entire period 1945-1949 causes major problems. In the case of Gubin district, it was possible to collect not only descriptive reports, but also tabular reports with the division into municipalities.

${ }^{4}$ Matters related to settlement in the district were initially within the competence of the Settlement Department at the District Branch of the PUR in Gubin, and from March 22, 1948 of the Settlement Office at the District Administrator.

${ }^{5}$ Archiwum Państwowe w Poznaniu (hereafter: APP), Państwowy Urząd Repatriacyjny Wojewódzki Oddział w Poznaniu (hereafter: PUR Poznań), sygn. 2767: Reports on rural settlement in Gubin district.

${ }^{6}$ APP, PUR Poznań, sygn. 2768: Reports on settlement in Gubin district.

${ }^{7}$ Archiwum Państwowe w Zielonej Górze (hereafter: APZG), Starostwo Powiatowe Gubińskie w Gubinie (hereafter: SPG), sygn. 36: Sprawy statystyczne ogólne 1948, k. 18-128 (Situational and statistical reports, 1948).

${ }^{8}$ Repatriation means "return to the homeland", but the proper term is expatriation, "forced expulsion from the homeland". Cf. Jerzy Surwiło, Zostali tu z nami na dobre i złe. Losy przedstawicieli inteligencji Wilna i Wileńszczyzny po 1944 (Wilno: Margi raštai, 2000), 8; Czesław Osękowski, "Proces zasiedlania Ziemi Lubuskiej po II wojnie światowej," Studia Zachodnie 5 (2000): 11. 
in good condition, while the pages are partly typescript and partly handwritten (sometimes in crayon).

The numerical statements of the administrator cannot be compared with the PUR data, because the latter do not take into account the indigenous people, Germans and Poles who arrived outside of PUR transports. Thus, the article largely analyzes the administrator's data as they were more complete. PUR statistics, in turn, allow us to capture the dynamics of migration (though incomplete). The data contained in the source may raise some doubts, as there are (minor) errors in summing up columns and rows, and errors in rewriting data from the tables sent by the municipal authorities. ${ }^{9}$

A further problem that resulted in gaps in the statistics was the arrival of individual family members or the abandonment of occupied properties / farms without informing the relevant authorities. In order to establish facts and check registers, PUR employees conducted field inspections. The sources contain information on two such inspections carried out in 1946 and 1947. In September 1946, the head of the PUR district branch wrote in his comments, "The absorptive capacity increased this month because settlers who had taken it upon themselves to abandon occupied settlements were deleted from the register." 10 The number of empty farms increased by $238(43 \%)$, the number of manned farms decreased by $145(-7 \%)$, and the number of inhabitants fell by $712(-11 \%)$. Similarly, in early 1947 , the governor wrote in his comments to the table, "The present report does not agree with the previous one, because the number of settlers has significantly decreased, which was uncovered by the inspection carried out in the district in February 1947. The present data should be treated as reliable and fully accurate."'l1 Thus, the number of families decreased by $17 \%$, and the number of occupied farms by $20 \%$, but the population fell by only $1 \%$ (see Table 1 ). The absorptive capacity increased by as much as $75 \%$.

${ }^{9}$ Particularly doubtful is the entry in the table on the state of settlement in November 1948, as the number of displaced families who came to Wałowice municipality was given as 51 , and the number of residents was given as 10.51 families could not amount to 10 people (perhaps it was supposed to be the other way round, with 51 people and 10 families), but these data add up to the number of families and people in December. APZG, SPG, sygn. 36, k. 121.

${ }^{10}$ APP, PUR Poznań, sygn. 2767, k. 27.

${ }^{11}$ Ibidem, sygn. 2768, k. 4 (list of repatriates and displaced persons), k. 8 (report, Feb. 1947), k. 7 (letter of the Head of the PUR District Branch in Gubin, March 3, 1947). 
Table 1. Change in number of inhabitants of rural communes in Gubin district following an inspection by the PUR in February 1947

\begin{tabular}{|c|c|c|c|c|c|c|c|c|}
\hline \multirow[b]{2}{*}{ District } & \multicolumn{4}{|c|}{ As of January 31, 1947} & \multicolumn{4}{|c|}{ As of February 28, 1947} \\
\hline & 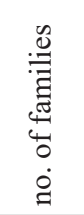 & 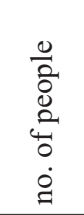 & 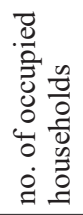 & 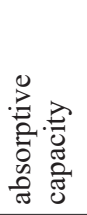 & 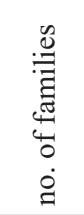 & 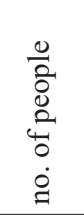 & 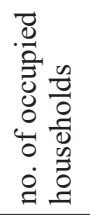 & 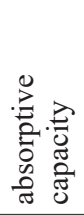 \\
\hline Biecz & 285 & 912 & 284 & 193 & 282 & 903 & 260 & 216 \\
\hline Czarnowice & 506 & 1,420 & 505 & 45 & 469 & 1,754 & 450 & 99 \\
\hline Markosice & 375 & 1,325 & 375 & 100 & 298 & 1,315 & 280 & 192 \\
\hline Pole & 264 & 968 & 264 & 154 & 216 & 816 & 215 & 203 \\
\hline Wałowice & 588 & 1,794 & 587 & 41 & 416 & 1,587 & 413 & 225 \\
\hline Total & 2,018 & 6,419 & 2,015 & 533 & 1,681 & 6,375 & 1,618 & 935 \\
\hline Difference & & & & & -337 & -44 & -397 & 402 \\
\hline Difference in $\%$ & & & & & -17.0 & -0.7 & -20.0 & 75.0 \\
\hline
\end{tabular}

Source: APP, PUR Poznań, sygn. 2768, k. 1, 4.

In all municipalities the number of occupied households and families decreased; only in the municipality of Czarnowice did the number of inhabitants increase. On the other hand, in the corresponding period, the report of the Gubin administrator indicated a general increase in the number of inhabitants; only in the commune of Pole was there a slight decrease in the number of inhabitants. ${ }^{12}$ It should be noted that the administrator based his calculations on lists of the residents' names and was not informed of all the changes. All this means that the data should be approached critically, but nevertheless they give the opportunity to capture trends in the inflow of inhabitants of the district. Moreover, the dynamics of migration was so great, especially in the first two years, that problems related to the registration of the population are not entirely surprising.

\section{The Expulsion of the Germans}

It is estimated that at the end of the war, about $30 \%$ of the German population remained in the Lubuskie Region, and $12 \%$ in Gubin district, i.e., c. 8,000 people. ${ }^{13}$ Following the declaration of peace in May 1945, some Germans fled west across

${ }^{12}$ APZG, SPG, sygn. 60, k. 13-41.

${ }^{13}$ Henryk Dominiczak, Proces zasiedlania województwa zielonogórskiego w latach 1945 1950 (Zielona Góra: Lubuskie Towarzystwo Naukowe, 1975), 29; Osękowski, "Nowi 'Lubuszanie'," 260; idem, Osadnictwo polskie na poniemieckich ziemiach po drugiej wojnie światowej. Ziemia Lubuska i powiat Gubin, http://www.transodra-online.net/pl/node/1411. 
the Oder and Nysa Łużycka rivers, but some returned to their homes. On June 20,1945, deportation of the remaining German population began, and c. 12,000 people were deported from the district. The representative of Gubin described the action in 1946 as follows: "In July 1945, the Germans were displaced by the 38th Infantry Regiment with the help of the [communist] police and secret police in Gubin; German specialists only were retained for work. In March this year, a transport of Germans from the district of Wrocław arrived. Because the border on the Niss is closed for now, the Germans were engaged in springtime work." "14

In August 1945, the Ministry of Public Administration made it possible for those Germans who could be used in the economy to stay in the country. ${ }^{15}$ After the Potsdam Conference, the issue of their expulsion was taken up by the Allied Control Council; according to the plan, the operation was to start in December 1945. Up to that point, voluntary displacement dominated, so the district was flooded by Germans "trying to get into one of the occupied zones."16

Figure 1. German population in Gubin district, 1945-1947

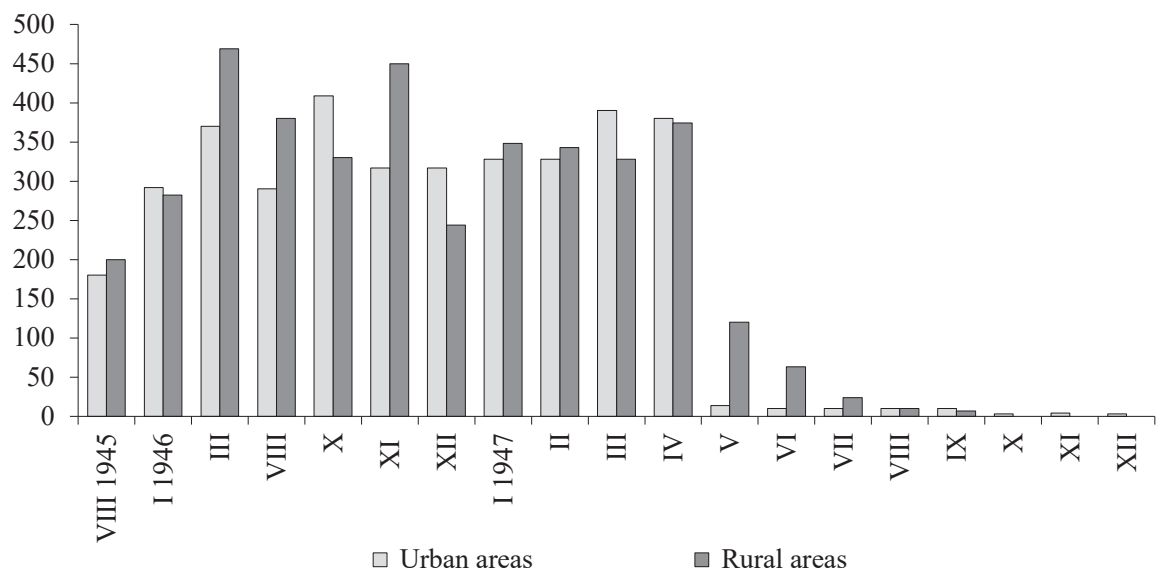

Source: own work based on the reports of the Gubin administrator.

${ }^{14}$ APZG, SPG, sygn. 54, k. 107 (letter, April 11, 1946) (own translation).

${ }^{15}$ Paweł Kacprzak, "Polityka władz polskich wobec ludności niemieckiej w okresie funkcjonowania Ministerstwa Ziem Odzyskanych," Czasopismo Prawno-Historyczne 62 (2010), 2: 218; Stanisław Jankowiak, "Wysiedlenia Niemców z Polski po II wojnie światowej," Pamięć i Sprawiedliwość. Biuletyn Głównej Komisji Badania Zbrodni przeciwko Narodowi Polskiemu Instytutu Pamięci Narodowej 2 (2004): 145.

${ }^{16}$ Jankowiak, "Wysiedlenia," 148-149; Bernadetta Nitschke, Wysiedlenie ludności niemieckiej z Polski w latach 1945-1949 (Zielona Góra: Wydawnictwo Wyższej Szkoły Pedagogicznej, 1999), 149. 
In Gubin district, the number of Germans increased significantly between the summer of 1945 and March 1946 (see Figure 1). In July 1945, there were 50 Germans in Gubin, in August their number had increased to 180, and in the countryside, there were 200 people. In the following months of 1946 this number continued to increase: in January it was 574, in August 682, in October 739, and in March of the following year, $718 .{ }^{17}$ On May 30, 1947, most of the Germans were deported. On May 31, there were still 120 in the town and 14 in the countryside, but in July only 34 were mentioned, and at the beginning of 1948, only 3, on March 15. From June 1948 to March 1949 there were no Germans in the district. In April 1949, there were 3 Germans in Gubin, and from July 2, this state lasted until the end of the year.

The Germans expelled in July 1945 were largely children, women and old people. In the following months, German people arrived from the east. Due to the temporary closure of the border and a lack of transports (especially in winter), their number increased in the district with each successive month. Therefore, people who were able to work were ordered to do so to support themselves and their families. They worked in craft workshops, industrial plants (e.g., in the Sock and Stocking Factory), or public institutions, as well as manual laborers on the land. The district authorities constantly complained about the lack of professionals in the economy, it was impossible to restart the former German factories and plants, and Poles with the appropriate qualifications were not arriving, so German workers were willingly employed. Some light on the issue of the increase in the number of Germans, which in the reports included the Volksdeutsche, is shed by the report of the administrator from January 1947: "There are about 164 Volksdeutsche in the district. These are people who are not locals, but mainly immigrants, detained last year on their way from the interior of Poland to Germany due to the closure of the border in the meantime; they are not seeking rehabilitation. They are stuck here and work for assigned employers." ${ }^{\prime 18}$ In October 1947, a group of 133 Volksdeutsche was still in the district, as they had been excluded from the forced expulsion, but they wanted to leave. ${ }^{19}$ At the end of 1948 the number of Volksdeutsche was 143; at the end of 1949 it was 43. ${ }^{20}$

${ }^{17}$ APZG, SPG, sygn. 54, k. 110, 111 (list, Aug. 20, 1946); k. 224-230 (state of settlement, Oct. 1946; APZG, SPG, sygn. 59, k. 14-15 (report, inflow to Aug. 30, 1946); k. 30, 46 (situational report, Dec. 1946); Dariusz A. Rymar, "Początki Ziemi Lubuskiej w świetle dokumentów (lutysierpień 1945)," Nadwarciański Rocznik Historyczno-Archiwalny 12 (2005): 193.

${ }^{18}$ APZG, Urząd Wojewódzki Poznański Ekspozytura w Gorzowie (hereafter: UWPEwG), sygn. 36, k. 6 (report, Jan. 1947).

${ }^{19}$ APZG, UWPEwG, sygn. 36, k. 40 (report, Oct. 1947).

${ }^{20}$ Ibidem, sygn. 36, k. 63 (quarterly report, 4th quarter 1948); k. 156 (quarterly report, 4th quarter 1949). 
After the war, a review of the local population began in the so-called Recovered Territories. Committees determined whether the people declaring their willingness to stay there were Poles. The Lubuskie Region had the fewest people positively assessed in the whole of the Recovered Territories. ${ }^{21}$ In September 1946 the number of indigenous people in Gubin district was 37, in November the administrator gave the number as 28, in March 1947, 34, and in May, $37 .{ }^{22}$ In the last quarter of 1947 and the first quarter of 1948, however, the administrator mentioned only 7 people confirmed as indigenous in the district, and in October 1949 this number was also 7 ( 2 families). ${ }^{23}$

Apart from Germans, several people of other nationalities lived in the district. In the years 1947-1949 there were a dozen (initially 19, later 13) Swiss (German-speaking, who owned their own farms inherited from their ancestors in Biecz and Bieżyce), 3 Czechs (machine mechanics in Gubin) and several Yugoslavs (unemployed), while in 1947 there were 2 Lithuanians, in 1948 and 1949 1 Belgian, and at the end of 1948, 4 Jewish families. ${ }^{24}$ At the end of 1948, people of other nationalities constituted only $0.2 \%$ of the district's population (21 people in total). In the third quarter of 1949, the administrator reported that there were no national minorities in the district, and the 5 Swiss families had left for Switzerland..$^{25}$

\section{An Influx of Polish Settlers}

From June 1945, the operation to settle the Recovered Territories was supervised by the PUR, established in October 1944, and the Ministry of the Recovered Territories, established in November $1945 .{ }^{26}$ Gubin district found itself in a peculiar situation, as there was almost no indigenous population, and the German population had either fled or been expelled, so the resulting population void had

${ }^{21}$ Until mid 1947, 7,600 people were recognized as Polish citizens in the Lubuskie Region. Osękowski, "Proces," 8.

${ }^{22}$ APZG, SPG, sygn. 60, k. 67 (state of the Polish population, March 31, 1947); sygn. 54, k. 336 (letter, Dec. 2, 1946); APP, PUR Poznań, sygn. 2768, k. 21 (letter, May 16, 1947); Dominiczak, Proces, 52. The operation finished at the end of 1947.

${ }^{23}$ APZG, UWPEwG, sygn. 36, k. 58 (report, 4th quarter 1947); k. 65 (general report, 1st quarter 1948); APZG, SPG, sygn. 42, k. 14 (administrator's letter, Oct. 10, 1949). Interestingly, the 1950 census showed 54 indigenous people in Gubin and as many as 433 in the countryside in Gubin district. Compared to the previous data, these numbers (a significant increase) cause doubt (see Dominiczak, Proces, 56). Narodowy Spis Powszechny z dnia 3 grudnia 1950 r. Miejsce zamieszkania ludności w sierpniu 1939 r. (Warszawa: GUS, 1955).

${ }^{24}$ APZG, UWPEwG, sygn. 36, k. 20 (letter, Aug. 4, 1947); k. 51 (letter, Dec. 12, 1947); k. 63 (report, 4th quarter 1948).

${ }^{25}$ Ibidem, sygn. 36, k. 145 (administrator's office report, 3rd quarter 1949).

${ }^{26}$ Osękowski, "Proces," 6-7. 
to be filled by Poles. This is how the district Commissioner at the time, Czesław Zalewski, described it in the summer of 1945: "The population is suffering from hunger and fleeing en masse to the opposite bank of the Neisse. There are no cattle and horses [...] There is no industry." 27 In July, it was reported: "Gubin is 75\% destroyed, and the surrounding area is mined and inaccessible. The villages have been abandoned and are almost deserted. The Germans were expelled beyond the Neisse, and in the villages, you meet Russians returning from work in Germany and Poles who are either returning from Germany, or who have come here from eastern Poland. The villages are empty, and livestock, living and dead, has been taken away by the army." 28

The proximity to the border with Germany raised concerns that the Germans would return to these areas. The arable land was of poor quality, and nearly every year there were natural disasters (hail, floods, drought, plagues of mice, and thistles). People were not encouraged to settle at the time due to problems related to food supplies, a lack of electricity and water in the first year or a lack of livestock. In the first months, it was impossible to get to Gubin via a direct train, as the station was on the German side. As one of the pioneers recalls, "Guben could only be reached by a light steam engine, due to the damaged surface, damaged tracks, bridges thrown together by the army and mines left over from the Nazi troops." 29 The repatriated and displaced people coming by train had to deal with another serious problem when they arrived - no means of transport. ${ }^{30}$ The people and their belongings walked from the station on foot or took a rented wagon. With time, it became easier to find transport, but it was not possible to go everywhere, e.g., Szydłów, located in the north of the district (about $20 \mathrm{~km}$ from Gubin), remained

\footnotetext{
${ }^{27}$ Hieronim Szczegóła, "Narodziny władzy ludowej w powiecie gubińskim i początki życia społeczno-politycznego w latach 1945-1946," in: Gubin, 69-70 (own translation).

${ }^{28}$ Dominiczak, "Osadnictwo," 52 (own translation). The Gubin area was heavily mined; only in 1946 did sappers remove 63.3k anti-personnel mines, $10.3 \mathrm{k}$ anti-tank mines and 143.9k artillery shells. The operation to de-mine the city and the district lasted until 1956. See Zygmunt Traczyk, "Wyzwolenie Gubina w 1945 roku," in: Gubin. Zarys historii miasta, ed. Czesław Osękowski (Zielona Góra: Lubuskie Towarzystwo Kultury, 1987), 32; idem, Ziemia gubińska 1939-1949... (Gubin: Stowarzyszenie Przyjaciół Ziemi Gubińskiej, 2011), 128-131.

${ }^{29}$ Czesław Szczepaniak, "Z oflagu do Gubina," in: Mój dom nad Odrą. Drugi tom wspomnień i pamiętników, compiled by Janusz Koniusz (Zielona Góra: Lubuskie Towarzystwo Kultury, 1965), 29 (own translation).

${ }^{30}$ Some of the people who came by transport did not want to leave the wagons, claiming that there were still Germans there. The district authorities explained this fear as coming from German propaganda. For example, in May 1946, none of those arriving at the Gubin stage wanted to get off the train. They were unloaded by force by the police and secret police officers, but that did not help either, as they did not want to leave the train station. Varying methods were used to encourage the arriving settlers to stay - they were taken around the district and shown farms ready to be taken over, and even the local priest was employed to confirm that it was safe there. APP, PUR Poznań, sygn. 2767, k. 11 (situational report, Apr. 1946), k. 16 (report, May 1946).
} 
uninhabited in 1948, because it was the only place located on the other side of the Oder River and had no line to the rest of the district. ${ }^{31}$

People arriving from mid-1946 onwards tended to settle in the countryside, as Gubin's economic opportunities were exhausted. Several "larger plants" were open (employing a maximum of 40-50 people, eventually 100 people) and the small number of state institutions did not offer a sufficient number of jobs, and craft and service companies were also at capacity. So even though houses stood vacant in the town, the lack of work effectively discouraged people from settling there. ${ }^{32}$ Therefore, people were keener to take over a farm, although farms in Lower Silesia, which were allocated with livestock, remained more attractive than those in Gubin. ${ }^{33}$ In the spring of 1946, Commissioner Czesław Kończak wrote to the voivodeship authorities, "The settlement operation in this area is in a very bad way. The settlers coming to our area are poverty-stricken and have no food supplies and for the most part there are no livestock, which causes great unhappiness and discourages them from settling here." 34

Further problems with settlement resulted from the operations of the Red Army and the Polish state itself. Polish settlers appeared relatively late in the district, as they had been prevented from doing so by the Soviet war commander (formally, no final decision had been made as to the delineation of the new Polish-German border). It was only at the beginning of June 1945 that he allowed the establishment of a Polish administration, and with its establishment, settlers began to arrive, including Poles returning from Germany. ${ }^{35}$ This influx was somewhat halted in June by the Polish state's plan to settle the districts along the border with

${ }^{31}$ Before the war, Szydłów was inhabited by only 22 people, and it did not recover after the war. Today only the name of the hamlet remains on maps. For more on subject, see Wiesław D. Łabęcki, “Szydłów - wieś, której już nie ma," Ziemia Lubuska 3 (2017): 31-44.

${ }^{32}$ In the spring of 1947 , the Settlement Office advertised no further possibility for the settlement of workers and craftsmen in the city, as the factories had to be opened first. APZG, SPG, sygn. 60: Sprawozdawczość i statystyka, k. 100 (report, May 1947). Por. APZG, UWPEwG, sygn. 36, k. 76 (report, 3rd quarter 1948); APP, PUR Poznań, sygn. 2769: Sprawozdania Referatu Ogólnego, k. 37 (report, May 1949).

${ }^{33}$ For example, in April 1949, the head of the PUR in Gubin wrote: "7 families, i.e., 25 people, came from the area of Limanowa who, after seeing farms in Niemaszchleba, decided not to settle there. They found that the land was not suitable for cultivation (marshy ground), they ordered wagons and at their own expense left for Kłodzko district in the Wroclaw voivodeship." Today, Niemaszchleba is the village of Chlebowo. APP, PUR Poznań, sygn. 2769, k. 46 (report by PUR, 31 Mar.-30 Apr. 1949).

${ }^{34}$ APZG, SPG, sygn. 54: Przepisy, zarządzenia ogólne i raporty sytuacyjne, k. 204 (letter, April 7, 1946).

${ }^{35}$ Henryk Dominiczak, "Początki władzy ludowej na obszarach obecnego województwa zielonogórskiego w 1945 r.," Polska Ludowa. Materiaty i Studia 7 (1968): 176. 
Germany by former soldiers (the so-called military settlement). ${ }^{36}$ However, in the fall of 1945, the state authorities realized that it would be impossible to settle the borderland with military settlers only. More and more permits for civil settlement began to be issued, all the more so as the inhabitants of former Polish lands now occupied by the USSR, and central Poland, were looking for new places to live. ${ }^{37}$

Military settlers came to the district from the end of July 1945. The literature emphasizes that they formed a high percentage of the population..$^{38}$ This is also confirmed by the data, although in the light of the (fragmentary) material, it should be modified. However, before I proceed to determining the number of these settlers, the statistics contained in the source material require explanation. The reports indicated the number of military settlers, but it should be remembered that the term military settlement should not only be understood as soldiers, but also their family members. As the families were not numerous at that time (see the section on the size of the family), the number of settlers given in the source can be tripled, and in 1949 , multiplied by 3.5. ${ }^{39}$

On July 31, 1945, 3 settled military families totaling 11 people were reported in the district, while a month later there was a total of 1,500 people. ${ }^{40}$ To Octo-

\footnotetext{
${ }^{36}$ In August 1945, it was reported, "Civil settlers are reluctant to settle in the district, because they receive a warning that they will eventually have to give their premises to military settlers," k. 9. For more on the subject of military settlement, see Krystyna Kersten, "Osadnictwo wojskowe w 1945 roku. Próba charakterystyki," Przeglad Historyczny 55 (1964), 4: 657-658; Arkadiusz Ogrodowczyk, Nad Odra i Bałtykiem. Osadnictwo wojskowe na zachodnich i pótnocnych ziemiach Polski po drugiej wojnie światowej (Warszawa: MON, 1979); Czesław Osękowski, Pionierzy w mundurach na Ziemi Lubuskiej (Zielona Góra: Lubuski Komitet Upowszechniania Prasy, 1985); Jerzy Czabator, "Osadnictwo wojskowe w powiecie gubińskim po II Wojnie Światowej," Gubin i Okolice. Biuletyn SPZG 2 (2013): 35-42. Ogrodowczyk mentioned two aims of this settlement: securing the border and a way of rewarding soldiers for participating in the war (Nad Odra, 54-55). Cf. Osękowski, "Oficjalne i faktyczne cele osadnictwa wojskowego na pograniczu polsko-niemieckim po drugiej wojnie światowej,” Stupskie Studia Historyczne 3 (1993): 58.

${ }^{37}$ There are a couple of interesting sources in the APP that deserve a separate study. These are Książi rejestracyjne repatriantów and Książki rejestracji przesiedleńców. They contain data including name and surname, date of birth, where the settler came from, profession, date of registration and address of settlement. The Books of Repatriates have 9,260 entries up to early 1948, and the Books of the Displaced have 2,661 entries up to October 1947. On their basis, it would be possible to determine the age of the settlers, the size of the family, as well as where they were born, i.e., where they came from APP, PUR Poznań, sygn. 2783, 2785, 2786: Książki rejestracyjne repatriantów, sygn. 2784: Książka rejestracyjna przesiedleńców.

${ }^{38}$ In fact, military settlers were visible in the district, but such a high percentage is not reflected in the source material. Military settlers formed one of the units of the Volunteer Fire Brigade, founded the District Union of Military Settlers, were the trustees of most of the mills in the district, and also established their own cooperative, Nysa (closed down at the end of 1948).

${ }^{39}$ The number of settlers in Ogrodowczyk, Nad Odra, was similarly estimated to be 164 . Of the numbers he provided in 1948, the average family consisted of 3 people $(164,170)$.

${ }^{40}$ APP, PUR Poznań, sygn. 2032: Reports on military settlements, Gubin district, k. 23 (Register of the movement of military settlers); k. 26 (report on the settlement operation, 1-10 Jan. 1946). Cf. Osękowski, Pionierzy, 48.
} 
ber 23, 1945, the Gubin District Residential Register listed 500 military settlers (families), while the next, to May 15, 1946, contained 1,688 people. ${ }^{41}$ On the other hand, the Alphabetical Index of Settlers, which contained a list of military settlers by surname with the place of residence (name of the borough) and the registration number lists 3,247 settlers to the end of 1946. Names have also been deleted and there is a note in the comments about leaving farms. ${ }^{42}$ According to reports, the military were in the worst situation among the settlers, because "they come in only what they are wearing, and without their families, who are still on the other side of the Bug." ${ }^{\prime 3}$

By February 1946, military settlers (1,600 people) had taken over 420 farms in the district and constituted the majority (61\%) of the district's inhabitants (there were 1,021 civilian settlers).$^{44}$ In August, there were 889 military settlers in the district, including 210 in the town, and in November, there were $1,181 .{ }^{45}$ On January 31,1947 , this number dropped to 1,069, in April it rose to 1,214, in August it fell again to 889, and at the end of the year it increased to 1,257. In February 1948, the number of military settlers decreased to 1,242, in April 1949 to 1,079, and fell to 1,006 people in September. ${ }^{46}$ These fragmentary data refer to military personnel; however, the number of their family members should also be estimated. Thus, the level of military settlement can be estimated in January 1947 at about 3,200 people, at the end of the year and at the beginning of the next at 3,800 people, in mid-1949 3,500, and in September 1949 about 3,500 people.

${ }^{41}$ APZG, SPG, sygn. 91: Register of settlers from 500 to 1,674. According to Ogrodowczyk (Nad Odra, 109), by the end of November 1945, 1,500 military settlers had settled in the district, according to the Military Settlement Commission, and 630 families (1,440 people) according to circuit supervisors.

${ }^{42}$ APZG, SPG, sygn. 92: Alphabetical index of settlers, k. 54. But by the summer there were problems with settlement, e.g., the Inspector of Military Settlement reported on August 21, 1945, "A group of settlers consisting of 20 families is refusing to take over farms because of minefields and the poor soil." (own translation) APP, PUR Poznań, sygn. 2032, k. 25.

${ }^{43}$ APP, PUR Poznań, sygn. 2032, k. 26 (Report from settlement operation, Jan. 1-10 1946).

${ }^{44}$ Ibidem, sygn. 2032, k. 30 (Survey no. 1, as of 15 Jan. 1946).

${ }^{45}$ APZG, SPG, sygn. 54, k. 110 (population list, 20 Aug. 1946); ibidem, sygn. 59, k. 26-39 (municipality list, 31 Dec. 1946. Cf. Ogrodowczyk, Nad Odra, 136, 138.

${ }^{46}$ Own calculations based on: APZG, SPG, sygn. 59, k. 26-39 (settlement status, Nov. 1946); APZG, SPG, sygn. 60, k. 28-41 (settlement status, II 1947); k. 77 (settlement status, V 1949); APZG, SPG, sygn. 43: Sprawozdania okresowo-statystyczne, k. 104 (settlement status, VI 1949), APP, PUR Poznań, sygn. 2676, k. 81 (settlement status list, XII 1947). Ogrodowczyk estimated the number of military settlers at the end of 1948 at around 2,000, and with their families at 6,000 (table 10, 163). However, he did not have data for the districts, but aggregate data for the Lubuskie Region, hence it seems that this number was significantly overestimated, because in the data for the district the number was at that time almost half. Czabator ("Osadnictwo," 41) incorrectly states that by 19491,840 military settlers had officially been granted farm ownership. The number cited by him refers to the total number of deeds issued in the district (cf. Hanna Kurowska, "Rolnictwo w powiecie gubińskim w latach 1945-1949" [in press]). 
The administrator's report from the last quarter of 1947 states that military settlers constituted $60 \%$ of the total number of employees in the district; ${ }^{47}$ however, if we analyze the numbers given in the lists which indicate the number of military settlers, we need take a critical view of this information. Military settlers constituted the majority of the district's inhabitants until the beginning of 1946. Later, the level of this settlement, in view of the influx of repatriates and displaced persons, decreased and came to a total of c. $27 \%$ in the county in August 1946 and at the beginning of $1947,30 \%$ a year later and c. $25 \%$ at the end of 1949.48 An analysis of the number of military settlers by municipality shows that the intensity of this type of settlement in the district was uneven and concentrated in the countryside. In August 1946, the largest number of military settlers lived in the municipality of Czarnowice (c. $53 \%$ of the population), while in the remaining rural municipalities they made up c. $30 \%$, and the smallest number of military families lived in Gubin (c. 14\%). In the years 1947-1949, the highest percentage of military settlers was in the municipality of Biecz (c. $90 \%, 95 \%$ and $80 \%$, respectively) and Pole (87\%, 83\% and 80\%). In the years 1947-1948, the military constituted almost half of the inhabitants of the Czarnowice municipality, but at the end of 1949 they made up only about $20 \%$ of the population. In the Markosice municipality, their numbers fell by half from $35 \%$ to $17 \%$, and in the Wałowice municipality the level was constant (c. 10\%), while the lowest percentage was recorded in Gubin, although here it doubled from c. $5 \%$ to $10 \%$.

In addition to the military settlers, inhabitants of the former eastern borderlands and central Poland came to the district. In October 1945, only half of 57 villages (27) were inhabited, and of the 2,400 former German farms, only 517 settlers had occupied them. ${ }^{49} \mathrm{By}$ the end of the year, 870 apartments were occupied in Gubin, 765 apartments were still to be occupied, with 1,871 farms in the countryside still vacant. ${ }^{50}$ The pace of settlement in this district, one of the most western in Poland, was unsatisfactory. The main settlement operation in the district lasted until the end of 1946; in the following year, the district was only "further settled [...] by people displaced from central Poland, who had decided to renovate the devastated farms." ${ }^{.11}$ Nevertheless, the pre-war population potential was not rebuilt.

${ }^{47}$ APZG, UWPEwG, sygn. 36, k. 58 (report, 4th quarter 1947).

${ }^{48}$ Osękowski reported that in March 1946 military settlers occupied over 25\% of all farms (Pionierzy, 53). Ogrodowczyk (Nad Odra, 163-164) and Osękowski (Pionierzy, 63) later wrote that in 1948 soldiers and their families constituted $49 \%$ of the county's population.

${ }^{49}$ APZG, SPG, sygn. 120: Powiatowy Urząd Ziemski w Gubinie - pisma okólne, korespondencja z władzami nadrzędnymi, sprawozdania z działalności, k. 258 (report, Oct. 1945).

${ }^{50}$ APP, PUR Poznań, sygn. 2766: Sprawozdania dotyczące osadnictwa miejskiego na terenie powiatu gubińskiego, k. 1 (list of repatriates and displaced persons to Dec 31 1945).

${ }^{51}$ Ibidem, sygn. 2768, k. 17 (descriptive report, April 1947). Mass migration ended for the entire Lubuskie Region in 1946, and it remained largely underpopulated. On the other hand, mass 
The sources provide a partial insight into the monthly number of repatriated and displaced people arriving in Gubin in the years 1946-1948 (Figure 2). Unfortunately, there are no data available for such a long period of time for the rural municipalities. The influx of people was dwindling with each passing year. ${ }^{52}$ By the end of 1945, 417 repatriates and 1,823 displaced persons had been settled in the city, in 1946 there were 1,144 repatriates and 1,496 displaced persons, 132 repatriates and 363 displaced persons in 1947, and in 1948 only 4 repatriates and 85 displaced persons. From February to the end of 1948, no repatriates came to the city. In total, 1,697 repatriates and 3,767 displaced persons were settled. The continuity of data for rural municipalities was preserved for 1946, when 3,174 repatriates and 883 displaced persons were settled. Statistics show that the repatriates dominated in the countryside (c. $70 \%$ of the population), and the displaced in Gubin (c. 75\%).

Figure 2. Number of repatriates and displaced persons settled per month in Gubin, 1946-1948

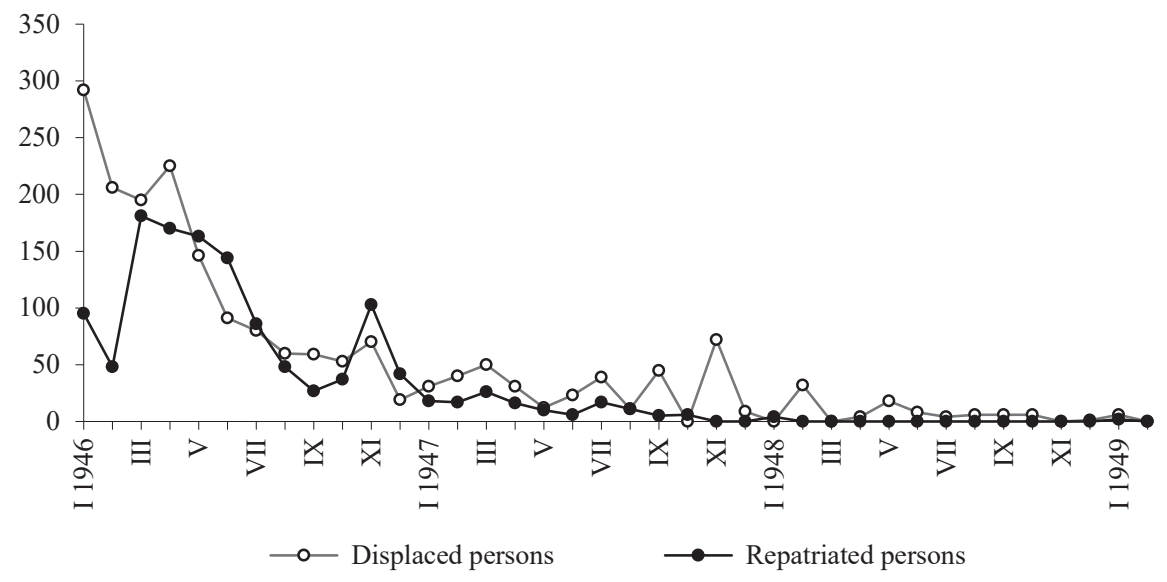

Source: APZG, SPG, sygn. 36; APP, PUR Poznań, sygn. 2766, 2768.

migration to the western territories in Poland ended two years later, in 1948. Cf. Stefan Banasiak, Działalność osadnicza Państwowego Urzędu Repatriacyjnego na Ziemiach Odzyskanych w latach 1945-1947 (Poznań: Instytut Zachodni, 1963), 152; Stanisław Łach, Osadnictwo wiejskie na ziemiach zachodnich i pótnocnych Polski w latach 1945-1950 (Słupsk: Wyższa Szkoła Pedagogiczna, 1983), 222.

${ }^{52}$ This also resulted from the intensity of the repatriation of Poles from the USSR; the most intense influx was in the first half of 1946: Henryk Słabek, O społecznej historii Polski 1945-1989 (Warszawa: Książka i Wiedza, 2015), 66-67. Por. Andrzej Gawryszewski, Ludność Polski w XX wieku (Warszawa: PAN IGiPZ, 2005), 442-443. 
Changes in the number of repatriates and displaced persons in the years 1946-1949 are shown in Figure 3. Unfortunately, there is no continuity of data, but until the beginning of 1947, the number of repatriated people exceeded the number of those displaced, and in 1948 both population groups were similar in numbers (this year was characterized by stabilization), so that in 1949 the number of displaced people prevailed. Every year, a decrease in the population arriving from Western Europe is visible, in 1947 by 15\%, and in 1949 by another 11\%.

Figure 3. Number of repatriated and displaced people settled in Gubin district, 1946-1949

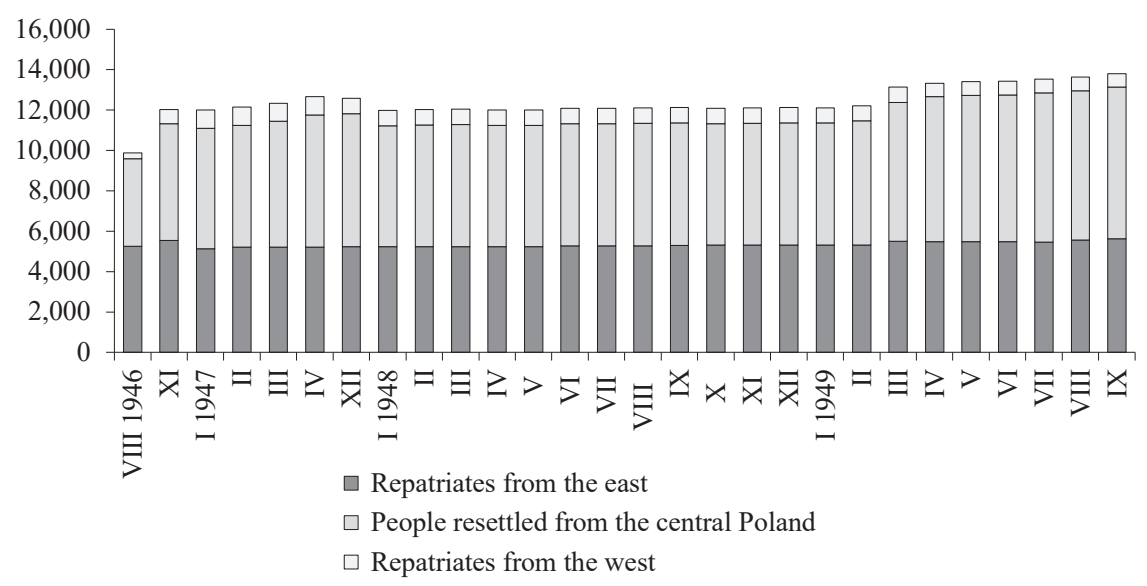

Source: APP, PUR Poznań, sygn. 2767; APZG, SPG, sygn. 36; sygn. 43; sygn. 54, sygn. 59.

The influx of Polish people to Gubin district was highly unsatisfactory. While by 1946 most of the districts of the Lubuskie Region were almost completely settled, only two of them, Krosno and Gubin, still had many vacant farms.${ }^{53}$ In January 1946, it was reported that 1,812 independent single-family farms of up to 15 ha were vacant in the district in the countryside, while there were 1,055 vacant houses.${ }^{54}$ In mid-1946, the absorption capacity decreased to 500 farms in the countryside and 81 houses in the city, and at the end of the year it was 570 in the countryside and 127 in the city. ${ }^{55}$ Two years later, there were still 420 farms vacant

${ }^{53}$ Franciszek Pastwa, Wieś lubuska w latach 1945-1950. Polityka i gospodarka (Zielona Góra: Lubuskie Towarzystwo Naukowe, 1977), 33.

${ }^{54}$ APZG, SPG, sygn. 54, k. 11 (survey to determine the settlement capacity of the Recovered Territories for the countryside); k. 12 (survey for towns).

${ }^{55}$ APP, PUR Poznań, sygn. 2767, k. 1 (population status, Dec. 31 1945), k. 25 (list, Aug. 1946); ibidem, sygn. 865: Wykazy cyfrowych danych dotyczących możliwości osiedlenia na Ziemi 
in the village, and about 1,000 families could be settled in the town. ${ }^{56}$ At the beginning of 1949, the administrator stated that 114 farms and 197 auxiliary farms remained in the village. ${ }^{57}$ In June he wrote, "Gubin has an abundance of vacant apartments. About 10,000 people could still settle in Gubin without major renovations. ${ }^{15}$ In mid-1949, the absorption capacity in the countryside was still high, with 145 farms and 197 auxiliary farms, which had not changed at the end of the year (141 farms and 192 auxiliary farms)..$^{59}$

\section{Population of the District}

In May 1939, about 44,000 people were permanent residents of Guben (the part located east of Nysa Łużycka had c. 28 thousand people), there were 45,400 in rural communes (the eastern part had 16,000), giving a total of 89,000 permanent residents. ${ }^{60}$ After the war, both the district and the town were divided between Germany and Poland, with Poland accounting for c. $44 \%$ of the pre-war area, 49,123 ha, including 27,000 ha (50\%) of forest, and 13,200 ha of arable land (c. $25 \%$ of the area). ${ }^{61}$

The arriving settlers faced quite difficult living conditions, so their number grew slowly, slowed down with time, and periodically decreased. This process was the most dynamic in the first year: in August 1945, the district numbered 3,500 people, in January 1946 4,757 people, in February 5,575 people and in March 6,472 people (Figure 4). ${ }^{62}$ In the following months of that year, the number of inhabitants increased significantly, although it is difficult to clearly establish the

Lubuskiej, k. 73 (list, Dec. 1946). In 1947, only two districts in the Lubuskie Region were excluded from settlement operations: Zielona Góra and Świebodzin. Cf. Banasiak, Działalność, 138-139, 145 .

${ }^{56}$ APZG, UWPEwG, sygn. 36, k. 58 (report, 4th quarter 1947).

${ }^{57}$ Ibidem, sygn. 36, k. 126 (report, 1st quarter 1949); APP, PUR Poznań, sygn. 2770: Sprawozdania z akcji przesiedleńczej w powiecie gubińskim, k. 17 (report, Jan. 1949).

${ }^{58}$ APZG, Powiatowa Rada Narodowa i Wydział Powiatowy w Gubinie, sygn. 1: Protokoły z posiedzeń Powiatowej Rady Narodowej w Gubinie; Nos. I-XV, k. 47 (protocol no. 6, June 1949).

${ }^{59}$ APP, PUR Poznań, sygn. 2770, k. 41 (report, June 1949); sygn. 2772: Sprawozdania z działalności osadniczej w powiecie gubińskim, k. 8 (report, Jan. 1950).

${ }^{60}$ Amtliches Gemeindeverzeichnis für das Großdeutsche Reich auf Grund der Volkszählung 1939, Berlin 1944, 63, 64; Wyniki spisu z 17 V 1939 r. w odniesieniu do ziem odzyskanych. Materiały Informacyjne Biura Studiów Osadniczo-Przesiedleńczych, z. 1 (Kraków, 1946), 13.

${ }^{61}$ APZG, SPG, sygn. 38: Sprawozdanie o sytuacji gospodarczej powiatu gubińskiego, k. 2; ibidem, sygn. 53: Statystyka gospodarcza, k. 5.

${ }^{62}$ Rymar, "Początki," 193; APZG, SPG, sygn. 38, k. 2-7; ibidem, sygn. 94: Sprawozdania statystyczne, k. 49 (letter, June 15 1946); k. 71 (population list); APP, PUR Poznań, sygn. 2764: Sprawozdania dotyczące osadnictwa wiejskiego w powiecie gubińskim, k. 2 (list of repatriates and displaced persons). 
number. For the end of August 1946, the sources provide two versions of the data: The Settlement Office counted 9,879 displaced persons and repatriates (it also mentioned 680 Germans), while the PUR counted 10,894 displaced persons and repatriates..$^{63}$ Thus, the data differed by about 1,000 inhabitants and perhaps that is why a review was made in September. After the PUR inspection, it turned out that 712 people had left the rural communes (c. 11\% of the population), the changes in numbers had not been noticed in the town, and the district itself had 10,262 inhabitants. Regardless of how many people actually left the district, this was caused by widespread famine (crops were destroyed by hail, flooding and mice, and there were problems with food supplies). ${ }^{64}$ In his report for September, the administrator wrote, "Every day a large number of people apply to leave the district for other areas. Ninety percent of them, however, are refused and we try to stop them from doing so in various ways. Our refusal, however, is not a particularly difficult obstacle for the settlers to overcome, and so we hear, 'So I'll take the cow on a rope, and the carthorse, and I'll be off,' and it turns out that these are not just empty words, because, as we said, they are mostly acted upon and after a week or two, it turns out that the settler has actually done it. The mass escape of settlers is clearly visible in our numerical report on rural settlement. We had about a hundred cases in our district this month. So, if we do not actually take appropriate remedial measures, the district will be depopulated by a large percent." ${ }^{65}$

The December report by the Settlement Department showed 12,168 people in the district, and the PUR data gave the number as 11,299 people. This time the data differ by about 1,000 people, but the higher number was now given by the Department. ${ }^{66}$ This time the number was not verified (perhaps this was the number of people who arrived independently of the PUR transport). In general, the increase in the number of inhabitants in 1946 was significant, about 2.5 times higher.

${ }^{63}$ APZG, SPG, sygn. 59, k. 14-15 (report, August 30, 1946). Importantly, fewer than 11,000 inhabitants were counted and thus far 3,662 repatriates and 2,013 displaced persons had passed through the PUR Stage Point in Gubin and through the West Point 2,527 repatriates, making a total of 8,202 people. The vast majority, $75 \%$, of those arriving by rail were repatriates. APP, PUR Poznań, sygn. 2761: Sprawozdanie z działalności Punktu Etapowego w Gubinie, k. 65 (summary of the movement of repatriated and displaced persons, Sept. 1946); APP, PUR Poznań., sygn. 2762: Sprawozdanie z działalności Punktu Etapowego w Gubinie, k. 6 (movements of repatriates to Aug. 31 1946).

${ }^{64}$ APP, PUR Poznań, sygn. 2767, k. 28 (explanatory table to the report for Sept. 1946).

${ }^{65}$ Ibidem, sygn. 2767, k. 31-32 (report, Sept. 1946).

${ }^{66}$ APZG, SPG, sygn. 59, k. 46 (report, Dec. 1946). 
Figure 4. Population of Gubin district, 1945-1949 (as of the end of each month)

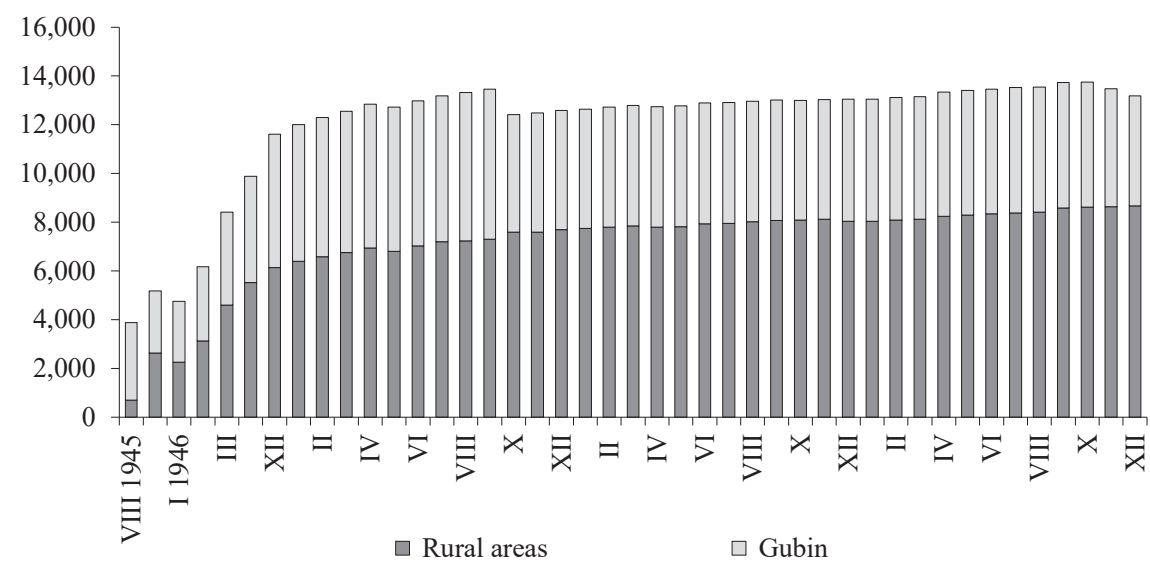

Source: own work, based on the sources.

Early 1947 saw the start of a small decrease in the population (c. 150 people), summed up by the head of the Settlement Department as follows: "It is no disaster for us that, for example, we will find families missing, because individuals who have left can be called inadequate, a weak link who have succumbed in the struggle for forging a better tomorrow and run away from work, and some of those who have left treated their stay in the West as just using the building entrusted to them, filling their pockets with money, and never as honest work. So now we need more and more people to come here and start work." ${ }^{967}$

When analyzing the dynamics of the changes in the district's population in the following years, it should be emphasized that the number of inhabitants at the end of 1946 (12,000 people) changed slightly in the following years. Another periodic outflow of population took place: on March 30, 1947, 12,842 people lived in the district, and 11,876 people in May. This loss of inhabitants is mainly the reduction of the town's population by $13 \%$, and the rural population by $2.5 \%$. Another outflow was recorded in the fall, and while in September the district had 13,457 people, a month later there were only $12,415 .{ }^{68}$ On October 31,1947 , the PUR reported that, of the planned settlement in the district of 4,843 families, 4,108 families had actually settled. "The shortcoming was caused by the destruction of the dams on the Oder River during military operations and the flooding

${ }^{67}$ APP, PUR Poznań, sygn. 2767, k. 40 (report, Feb. 1947).

${ }^{68}$ APZG, UWPEwG, sygn. 36: Sprawozdania sytuacyjne Starostwa Powiatowego w Gubinie, k. 24 (letter, Aug. 4, 1947); k. 54 (letter, Dec. 9, 1947). 
of large areas of the district." ${ }^{69}$ Another loss of over a thousand inhabitants was due to a further outflow of people from Gubin, whose population decreased by as much as $20 \%$. This fact can be associated with the earlier deportation from the district of a large group of Germans (c. 700), who largely supplied the market with both skilled and unskilled labor. In addition, the district was once again hit by natural disasters, exacerbating supply problems. The problems for the town's inhabitants could also have been aggravated by the nationalization of many companies (the trustees of former German property were losing their jobs). At the end of the year, the district was inhabited by 12,600 people.

The number of inhabitants stabilized in 1948 (at c. 13,000), increasing by only $3 \%$, with the number of people in the countryside (4\%) slightly more than in the town $(2.5 \%)$. In the following year, the district still had c. 13,000 residents. While the number of rural inhabitants increased from 8,000 to $8,700(8 \%)$, the number of Gubin residents decreased from 5,000 to 4,000 ( $-10 \%$, with $12 \%$ of these leaving in the fall only). In period under study, Gubin district was the least numerically and densely populated district in Lubuskie Region. ${ }^{70}$

Table 2. Population of the municipalities in Gubin district (1946-1949)

\begin{tabular}{lrrrrrr}
\cline { 2 - 7 } & Gubin & $\begin{array}{c}\text { Biecz } \\
\text { mun. }\end{array}$ & $\begin{array}{c}\text { Czarnowice } \\
\text { mun. }\end{array}$ & $\begin{array}{c}\text { Markosice } \\
\text { mun. }\end{array}$ & $\begin{array}{r}\text { Pole } \\
\text { mun. }\end{array}$ & $\begin{array}{c}\text { Wałowice } \\
\text { mun. }\end{array}$ \\
\hline Feb. 14 1946 & 3,040 & 426 & 1,078 & 461 & 351 & 818 \\
Aug. & 4,362 & 838 & 1,614 & 1,063 & 720 & 1,282 \\
Jan.1947 & 5,620 & 1,045 & 1,644 & 1,337 & 839 & 1,529 \\
June & 5,160 & 974 & 1,854 & 1,482 & 868 & 1,759 \\
Dec. & 4,895 & 1,205 & 1,890 & 1,686 & 886 & 2,021 \\
June 1948 & 4,964 & 1,260 & 1,985 & 1,747 & 914 & 2,026 \\
Dec. & 5,013 & 1,339 & 2,106 & 1,638 & 978 & 1,982 \\
June 1949 & 5,125 & 1,388 & 2,247 & 1,757 & 1,028 & 2,051 \\
Dec. & 4,520 & 1,432 & 2,269 & 1,741 & 1,075 & 2,147 \\
\hline
\end{tabular}

Source: own work based on the sources.

When we analyze the individual municipalities in the years 1946-1949 (see Table 2), we should note that compared to the census data from 1946, the highest increase in the number of inhabitants, almost fourfold, was recorded in the

\footnotetext{
${ }^{69}$ Państwowy Urzad Repatriacyjny Oddziat Poznański 1945-1948 (Poznań, 1949), 49.

${ }^{70}$ In early 1946, Babimojski and Skwierzyński districts (c. 9,000 people each) had slightly more inhabitants. In mid 1947, the population was smaller only in the area of Skwierzyński (almost 10,000 people), a similar number of inhabitants, c. 12,000, was located in the area of Babimojski. This situation did not change until the end of the period under analysis. Cf. APP, PUR Poznań, sygn. 228: Zestawienie osadnictwa na Ziemi Lubuskiej, k. 10 (report, June 1947).
} 
Markosice municipality, there was a 3.5-fold increase in the Biecz municipality, in the municipality of Pole the population tripled, increased 2.5 times in the municipality of Wałowice, doubled in the municipality of Czarnowice and the weakest increase was recorded in Gubin, with only $50 \%$. It is significant that the only town in the district that had been settled so enthusiastically in the first year, was later the worst-developing municipality.

To sum up, the population of the district increased 3.5 times (340\%) from August 1945 to the end of 1949 , but that of the town of Gubin by only $42 \%,{ }^{71}$ and the countryside had a 12-fold increase. The largest increase was observed until the end of 1946; the number of the district's population increased threefold, with that of the towns and cities almost doubling (182\%), and the that of villages going up nine times $(912 \%)$. It should be noted that the increase in the number of inhabitants in the first post-war year was disrupted in the following years by population losses caused by the lack of jobs, parceling and expropriation operations, and natural disasters that aggravated supply problems, as well as defections abroad.72 At the end of 1949, the town's population was only $16 \%$ of its pre-war state, and $54 \%$ of the countryside, which clearly demonstrates the poor settlement of this district.

\section{Structure of the District's Inhabitants}

The sources make it possible to determine the structure of society in Gubin district. If we examine the place of residence, the dominance of the rural population increased year on year. At the end of $1945,51 \%$ of the district's inhabitants lived in the countryside, a year later it was $52.5 \%$, in $194761 \%$, and at the end of 1949 it reached $66 \%$ of the population..$^{73}$ The structure of the district's inhabitants over the period is most accurately characterized by two censuses: the General Census (02/14/1946) and the census of the inhabitants of the Recovered Territories (12/31/1948).

In the light of the 1946 census, there were almost 109 women per 100 men in Gubin, 107 in rural areas, with the average for the Poznań voivodeship being as high as $118 \mathrm{~F}$ to $100 \mathrm{M}$, and in the country $121.5 \mathrm{~F}$ to $100 \mathrm{M}^{74}$ The highest feminization rate was in the municipality of Czarnowice (114 F to $100 \mathrm{M}$ ), and the lowest

${ }^{71}$ In Poland, small towns (including Gubin) had the lowest population growth rate in the years 1945-1950.Gawryszewski, Ludność, 126.

${ }^{72}$ APZG, UWPEwG, sygn. 36, k. 146 (report, 3rd quarter 1949).

${ }^{73}$ The percentage of the urban population in the Recovered Territories was higher than the average in Poland, which was 32\% in 1946 and $37 \%$ in 1950.

${ }^{74}$ Powszechny Sumaryczny Spis Ludności z dn. 14 II 1946 r. (Warszawa: GUS, 1947). Cf. Gawryszewski, Ludność, 211. 
in the municipality of Pole ( $91 \mathrm{~F}$ to $100 \mathrm{M}$ ). Looking at the age structure (there were three economic age groups in the census), $64.2 \%$ of the population was aged $18-59,31.5 \%$ were children and adolescents, and $4.3 \%$ were 60 years of age and older. ${ }^{75} \mathrm{~A}$ characteristic feature of post-war Gubin was a very high share of working-age population (70.5\%), with children and adolescents constituting only $26 \%$, and people of post-working age only $3.5 \%$. The age structure of the town differed significantly from the traditional picture, where there are relatively large numbers of children alongside people of working age. ${ }^{76}$ In villages, the percentage of people aged 18-59 was lower and came to $58 \%$, but there were more children and adolescents (37\%) and very elderly people (5\%).

A One-Time Report as of December 31, 1948 was drawn up for the census of the Recovered Territories. ${ }^{77}$ It includes such features as gender, age (also in three age groups, but the $0-17$ age group is divided into $0-3$ and $4-17$ years old), nationality and place of origin. The district had 13,056 permanent residents and 435 temporary residents. The rural population was most numerous, with only one in three people living in the town (38.4\%). Compared to the 1946 census, the feminization rate had not changed and was still $108 \mathrm{~F}$ to $100 \mathrm{M},{ }^{78}$ but for individual municipalities the changes were large. In towns, this ratio increased to 112, while in rural municipalities it dropped to 106. This shows a greater inflow of women to urban areas, and men to the countryside..$^{79}$ There were still more men than women in the Pole municipality ( $97 \mathrm{~F}$ to $100 \mathrm{M}$ ), and the largest number of women was in the Biecz municipality (115 F to $100 \mathrm{M})$. The feminization rate also differed in the subsequent age groups. The highest was for people aged 60 and over, coming to $174 \mathrm{~F}$ to $100 \mathrm{M}$ (in the municipality of Czarnowice it was 260, and in Gubin 219), while among people of working age there were $110 \mathrm{~F}$ to $100 \mathrm{M}$, and among the youngest (under 18 years) the number of men and women was comparable.

The age structure of the district's population changed, as there were more children (see Figure 5). Every second person (58\%) was 18-59 years old, every

${ }^{75}$ On average, people under the age of 18 in Poland accounted for $54.4 \%$ of the population, 18-59-year-olds 36.7\%, and 60 and above 8.9\%. Cf. Powszechny Sumaryczny Spis Ludności; Łach, Osadnictwo, 226-227

${ }^{76}$ Marek Okólski, Agnieszka Fihel, Demografia. Wspótczesne zjawiska i teoria (Warszawa: Wydawnictwo Naukowe Scholar, 2012), 68.

${ }^{77}$ For more, see Patrycy Dziurzyński, "Spis ludności na Ziemiach Odzyskanych z dnia 31 grudnia 1948," Polska Ludowa. Studia i materiaty 6 (1967): 183-188. It should be added that the statistical material given by the author shows the population according to voivodeships and districts, with the division into urban and rural municipalities (it does not include individual municipalities in numbers).

${ }^{78}$ On December 31, 1949, the feminization rate was further reduced to $107 \mathrm{~F}$ to $100 \mathrm{M}$. APZG, SPG, sygn. 42, k. 37 (population status, 4th quarter 1949).

${ }^{79}$ Generally, in the Lubuskie Region, the number of men increased and large disproportions in the number of both sexes decreased. Cf. Łach, Osadnictwo, 227. 
fourth person was 4-17 years old, every eighth person was born after the war ( $0-3$ years old), and every 25 th person was 60 years old or over. The youngest inhabitants (under 18 years of age) accounted for $38 \%$ of the total population, so it was a young community of the progressive type.$^{80}$ It should be remembered that 3 years previously, adults had made up as many as $64 \%$ of the population, with only $31 \%$ children and adolescents. There was still a higher percentage of people of working age in Gubin: $63 \%$, and in the countryside, $55 \%$. There was a significant increase in the share of children in the population especially those born after the war; the highest percentage was recorded in Gubin (13.7\%), and in municipalities it was around $12 \%$. Older children (4-17 years old) were most numerous in the municipality of Czarnowice (31.4\%) and the smallest number was in Gubin $(20 \%)$, while the largest number of people aged 18-59 was also in the town, the lowest in the was in the municipality of Czarnowice (53\%). The highest percentage of people aged 60 and above was in the Markosice municipality (5.5\%), and the lowest in the Czarnowice commune (3.4\%).

Figure 5. Age structure (in years) of the district's population as of December 31, 1948

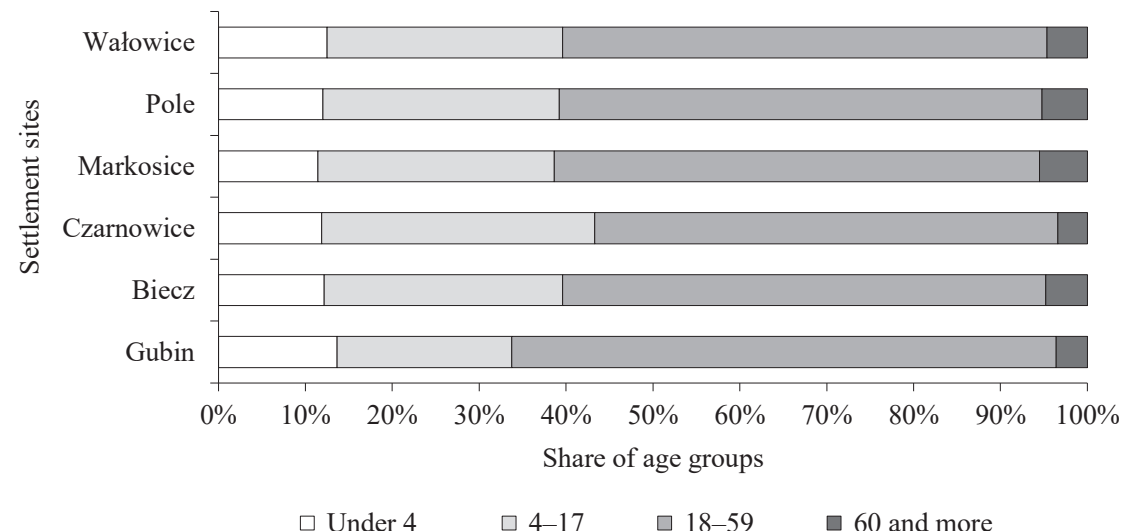

Source: APZG, SPG, sygn. 41: Statystyka ludnościowa, k. 86.

${ }^{80}$ The population of this district in comparison with the inhabitants of Lubuskie Region and the whole of the Recovered Territories was distinguished by its age structure. It was younger, with the percentage of children and adolescents under 18 higher than that of the remaining LR districts $(36.4 \%)$ and even higher than the total of the Recovered Territories $(34 \%)$. In particular, there were many children under $4,12.6 \%$, while for the RT the figure was $3.2 \%$. On the other hand, the percentages were lower in the populations of working age $(58 \%$ in Gubin district, $58.4 \%$ in the LR and $59.6 \%$ in the RT) and post-working age (4.2\% in Gubin district, $5.2 \%$ in the LR and $6.4 \%$ in the RT). Own calculations based on P. Dziurzyński, "Spis," 195. 
For every 100 people of Polish nationality in the district (see Table 3) there were 46 people displaced from central Poland, 38 repatriates from the USSR, 13 children born after the war, and 3 repatriates and re-emigrants from other countries. Most of the re-emigrants came from Germany (325 people), then from France (41), the Czech Republic (35), East Africa (5), Lithuania (4), Italy (2) and England (1) ${ }^{81}$ The indigenous population was small (12 people), the lowest in the Lubuskie Region, where, according to the 1948 census, there were 9,300 indigenous people. ${ }^{82}$

Table 3. Polish population of Gubin district by place of origin as of December 31, 1948

\begin{tabular}{lccccc}
\hline Town/municipality & $\begin{array}{c}\text { Children, } \\
\text { 0-3 years }\end{array}$ & Locals & $\begin{array}{c}\text { Repatriates } \\
\text { from } \\
\text { the USSR }\end{array}$ & $\begin{array}{c}\text { Repatriates } \\
\text { and re-emi- } \\
\text { grants from } \\
\text { other countries }\end{array}$ & $\begin{array}{c}\text { Resettled } \\
\text { from central } \\
\text { Poland }\end{array}$ \\
\hline Gubin & 684 & 7 & 878 & 217 & 3,219 \\
Biecz & 162 & 3 & 734 & 50 & 381 \\
Czarnowice & 250 & 1 & 968 & 7 & 880 \\
Markosice & 187 & 1 & 908 & 37 & 505 \\
Pole & 117 & 0 & 499 & 68 & 290 \\
Wałowice & 248 & 0 & 1,032 & 34 & 668 \\
Towns & 684 & 7 & 878 & 217 & 3,219 \\
Rural municipalities & 964 & 5 & 4,141 & 196 & 2,724 \\
\hline Total & 1,648 & 12 & 5,019 & 413 & 5,943 \\
\hline Total in \% & 12.6 & 0.1 & 38.5 & 3.2 & 45.6 \\
\hline
\end{tabular}

Source: APZG, SPG, sygn. 41: Statystyka ludnościowa, k. 86.

With the information on the number of families in the district and the number of inhabitants, it is possible to determine the size of the family, bearing in mind that the war period strongly influenced its shape and size (there were frequent single-parent families). The average size of the Gubin family continued to grow: in September 1946 it numbered 2.9 people, in early 1947 it was 3.1, by the end of the year it had decreased to 2.9, and in the following year 3.6. At the end of 1945, the urban family had 2.4 people, in mid-1946 2.6 people, in 19472.5 people, and at the end of that year 2.3 people, in 19482.7 people, and in 1949 almost 3 people. The rural family was larger: 3.1 people in mid-1946, 3.7 in mid-1947, 3.9 a year later and 4.2 in mid-1949. The increase in the number of family members indicates that complete families came more often, and the number of children increased.

${ }^{81}$ APZG, SPG, sygn. 41: Statystyka ludnościowa, k. 85 (One-time report on the population of the Recovered Territories, Dec. 31, 1948. Summary A).

${ }^{82}$ Dziurzyński, "Spis,” 202. 
Immediately after the war, single people often came, and with time the rest of the family joined them.

There were also visible differences in the number of repatriated and displaced families. In mid-1946, the repatriate family numbered 3.3 people, ${ }^{83}$ a year later 3.5, in mid-1948 3.8 and in 19494.2 people. On the other hand, the resettling family was smaller and consisted of 2.7 people, and in 1949 it grew to 3 people. Generally, it should be stated that the family size in the town of Gubin was smaller than that of the rural family, and the repatriate family was larger than the relocated family.

\section{Conclusion}

The post-war population situation in Gubin district gave an image of underpopulation. Of the 28,000 residents in pre-war Gubin (the right bank), there were only 4,500 people at the end of 1949 (16\% of the pre-war population), and the villages of about 16,000 inhabitants in 1939 had only 8,700 inhabitants 10 years later (54\%). Despite vacant farms, there were no people willing to take them over. In the first months after the war the settlement operation was dynamic and the population grew month on month, but local difficulties often turned out to be too great to overcome and the discouraged inhabitants left the district. The basic problems were poor soil, a lack of livestock and jobs, and state policy, combined with natural disasters which exacerbated food supply issues. The number of inhabitants in the district grew, although not systematically: in August 1945 it came to 3,900 people, at the beginning of 19464,800 people, in August there were 10,900 and at the end of the year the population reached 12,100. In the following years, it oscillated between 12,000 and 13,500 people. There were several large outflows, with a significant decrease in the rural population recorded in the fall of 1946, and in the urban population in the spring (of 13\%) and fall of 1947 (of $22 \%$ ) and in the fall of 1949 (of 12\%). It was a heavily feminized society, with a high percentage of people of working age. The displaced population predominated in the town, and repatriates in the countryside. Family size in the district was not large: in September 1946 it was 2.9 people, and in 19493.6 people, with the urban family smaller than the rural one, and the family of displaced people smaller than that of repatriates.

The potential increase in the number of inhabitants of Gubin and the entire district had to be associated with changes in the local economic situation, mainly with the creation of larger industrial plants and the improvement of the food

\footnotetext{
${ }^{83}$ According to Słabek (O spolecznej historii, 67) only 38\% of adult repatriates at that time were men.
} 
supply. The administrator often emphasized this fact in his letters, and it was also relied on when developing the 6-Year Plan (1950-1955). However, in those years the population of the towns and rural municipalities did not increase significantly (in 1955 the district had 14,500 people).

\section{Bibliography}

\section{Primary Sources}

Archiwum Państwowe w Poznaniu

Państwowy Urząd Repatriacyjny Wojewódzki Oddział w Poznaniu (PUR Poznań), sygn. 228, 2032, 2761, 2762, 2764, 2766-2770, 2772.

Archiwum Państwowe w Zielonej Górze

Starostwo Powiatowe Gubińskie w Gubinie (SPG), sygn. 36, 38, 41-43, 53, 54, 59, $60,91,92,120$.

Urząd Wojewódzki Poznański. Ekspozytura w Gorzowie (UWPEwG), sygn. 36.

Powiatowa Rada Narodowa i Wydział Powiatowy w Gubinie, sygn. 1.

\section{Secondary Sources}

Amtliches Gemeindeverzeichnis für das Großdeutsche Reich auf Grund der Volkszählung 1939. Berlin, 1944.

Narodowy Spis Powszechny z dnia 3 grudnia 1950 r. Miejsce zamieszkania ludności w sierpniu 1939 r. Warszawa: GUS, 1955.

Państwowy Urzad Repatriacyjny Oddział Poznański 1945-1948. Poznań, 1949.

Powszechny Sumaryczny Spis Ludności z dn. 14 II 1946 r. Warszawa: GUS, 1947.

Wyniki spisu z 17 V 1939 r. w odniesieniu do ziem odzyskanych. Materiały Informacyjne Biura Studiów Osadniczo-Przesiedleńczych. Z. 1. Kraków, 1946.

\section{References}

Banasiak, Stefan. Działalność osadnicza Państwowego Urzędu Repatriacyjnego na Ziemiach Odzyskanych w latach 1945-1947. Poznań: Instytut Zachodni, 1963.

Czabator, Jerzy. "Osadnictwo wojskowe w powiecie gubińskim po II Wojnie Światowej." Gubin i Okolice. Biuletyn SPZG 2 (2013): 35-42.

Dominiczak, Henryk. "Początki władzy ludowej na obszarach obecnego województwa zielonogórskiego w 1945 r.," Polska Ludowa. Materiaty i Studia 7 (1968): 161-181.

Dominiczak, Henryk. Proces zasiedlania województwa zielonogórskiego w latach 19451950. Zielona Góra: Lubuskie Towarzystwo Naukowe, 1975.

Dominiczak, Henryk. "Osadnictwo i stosunki demograficzne w powiecie gubińskim w latach 1945-1960.” In: Gubin, ed.Wiesław Sauter, 47-66. Zielona Góra: Lubuskie Towarzystwo Kultury, 1971.

Gawryszewski, Andrzej. Ludność Polski w XX wieku. Warszawa: PAN IGiPZ, 2005. 
Jankowiak, Stanisław. "Wysiedlenia Niemców z Polski po II wojnie światowej," Pamięć i Sprawiedliwość. Biuletyn Głównej Komisji Badania Zbrodni przeciwko Narodowi Polskiemu Instytutu Pamięci Narodowej 2 (2004): 139-160.

Kacprzak, Paweł. "Polityka władz polskich wobec ludności niemieckiej w okresie funkcjonowania Ministerstwa Ziem Odzyskanych.” Czasopismo Prawno-Historyczne 62 (2010), 2: 215-235.

Kersten, Krystyna. “Osadnictwo wojskowe w 1945 roku. Próba charakterystyki.” Przegląd Historyczny 55 (1964), 4: 640-659.

Łabęcki, Wiesław D. "Szydłów - wieś, której już nie ma.” Ziemia Lubuska 3 (2017): 31-44.

Łach, Stanisław. Osadnictwo wiejskie na ziemiach zachodnich i północnych Polski w latach 1945-1950. Słupsk: Wyższa Szkoła Pedagogiczna, 1983.

Nitschke, Bernadetta. Wysiedlenie ludności niemieckiej z Polski w latach 1945-1949. Zielona Góra: Wydawnictwo Wyższej Szkoły Pedagogicznej, 1999.

Ogrodowczyk, Arkadiusz. Nad Odra i Battykiem. Osadnictwo wojskowe na zachodnich i pótnocnych ziemiach Polski po drugiej wojnie światowej. Warszawa: MON, 1979.

Okólski, Marek, Agnieszka Fihel. Demografia. Współczesne zjawiska i teoria. Warszawa: Wydawnictwo Naukowe Scholar, 2012.

Osękowski, Czesław. "Proces zasiedlania Ziemi Lubuskiej po II wojnie światowej." Studia Zachodnie 5 (2000): 5-14.

Osękowski, Czesław. "Nowi 'Lubuszanie' wobec problemów osadniczych i politycznych na Ziemi Lubuskiej w latach 1945-1956. Opór - przystosowanie - uległość.” Studia Paradyskie 28 (2018): 255-291.

Osękowski, Czesław. "Oficjalne i faktyczne cele osadnictwa wojskowego na pograniczu polsko-niemieckim po drugiej wojnie światowej.” Stupskie Studia Historyczne 3 (1993): 53-66.

Osękowski, Czesław. Osadnictwo polskie na poniemieckich ziemiach po drugiej wojnie światowej. Ziemia Lubuska i powiat Gubin. http://www.transodra-online.net/pl/ node/1411.

Osękowski, Czesław. Pionierzy w mundurach na Ziemi Lubuskiej. Zielona Góra: Lubuski Komitet Upowszechniania Prasy, 1985.

Pastwa, Franciszek. Wieś lubuska w latach 1945-1950. Polityka i gospodarka. Zielona Góra: Lubuskie Towarzystwo Naukowe, 1977.

Rymar, Dariusz A. "Początki Ziemi Lubuskiej w świetle dokumentów (luty-sierpień 1945)." Nadwarciański Rocznik Historyczno-Archiwalny 12 (2005): 173-286.

Słabek, Henryk. O społecznej historii Polski 1945-1989. Warszawa: Książka i Wiedza, 2015 .

Surwiło, Jerzy. Zostali tu z nami na dobre i złe. Losy przedstawicieli inteligencji Wilna i Wileńszczyzny po 1944. Wilno: Margi raštai, 2000.

Szczegóła, Hieronim. "Narodziny władzy ludowej w powiecie gubińskim i początki życia społeczno-politycznego w latach 1945-1946.” In: Gubin, ed. Wiesław Sauter, 67-80. Zielona Góra: Lubuskie Towarzystwo Kultury, 1971. 
Szczepaniak, Czesław. “Z oflagu do Gubina.” In: Mój dom nad Odra. Drugi tom wspomnień i pamiętników, compiled by Janusz Koniusz, 28-30. Zielona Góra: Lubuskie Towarzystwo Kultury, 1965.

Traczyk, Zygmunt. Ziemia gubińska 1939-1949... Gubin: Stowarzyszenie Przyjaciół Ziemi Gubińskiej, 2011.

Traczyk, Zygmunt. “Wyzwolenie Gubina w 1945 roku.” In: Gubin. Zarys historii miasta, ed. Czesław Osękowski. Zielona Góra: Lubuskie Towarzystwo Kultury, 1987.

\section{Population of Gubin District in the Context of Situational and Statistical Reports in the Years 1945-1949}

\section{Summary}

The article was written on the basis of post-war accounts and reports by the Gubin district administrator and State Repatriation Office. The process of displacement of the German population, the influx of military settlers, repatriates and displaced persons along with the structure of the population by sex, age and place of origin are described. In June 1945, the deportation of Germans from the district began with c. 12,000 former inhabitants deported, but in the next few months German people were brought into the district or arrived on foot from the east. Due to the temporary closure of the border and a lack of transports (especially in winter), their number increased. At the beginning of 1946, 574 Germans were counted, in August, 682 and in October, 739. On May 30, 1947, most of the Germans were deported, on May 31, there were 134, in July, 34 and at the beginning of 1948, only 3 people remained. From mid-1948 to March 1949, there were no German inhabitants in the district. In April 1949, there were 3 Germans in Gubin, and from July there were only 2 . This number remained until the end of the year.

The influx of people in 1945-1949 was insufficient to rebuild the pre-war population potential. In 1939, the eastern part of the Gubin district, which in 1945 became Poland, was inhabited by 44,000 people, but in August 1945 the district had only 3,500 residents, and in January 1946, 4,800. With the influx of people, this number increased to 12,000 at the end of 1946, and at the end of 1949 to 13,100 residents. The only slight increase in population over these 3 years would suggest a decline in the inflow of people, but the influx, although weaker and weaker, continued; on the other hand, previous settlers left the district, which they considered unsuitable: the poor-quality soil, the lack of transport links, livestock and jobs, as well as concerns about the proximity of the border with Germany were mentioned. Every year, the area was also hit by natural disasters (hail, floods, drought, plagues of mice, and thistle), which exacerbated the existing food supply problems.

In the period under analysis, the district was the least numerous and most sparsely populated in the Lubusz Region. The total number of residents from August 1945 to the end of 1949 increased by $340 \%$, while the town of Gubin saw only a $42 \%$ increase, and 
the countryside saw a 12-fold increase. The highest population growth was observed until the end of 1946, with a threefold increase in the number of the district's inhabitants. There were several significant population losses: in the fall of 1946, in the spring and fall of 1947, and in the fall of 1948. At the end of 1945, half of the district's inhabitants lived in the town but in the following years the population settled mainly in the countryside and thus, at the end of 1949 , villagers accounted for $66 \%$ of the population. Compared to the voivodeship and the country as a whole, the district was characterized by a relatively low feminization rate (108 F:100 M). Gubin was dominated by people displaced from central Poland (c. $70 \%$ of the population), and in the countryside, repatriates (also c. $70 \%$ ). Military settlers and their families constituted a large percentage of the inhabitants $(25-30 \%)$. At the beginning of 1946, they made up over half of the district's population but in the following years their share in the total number of residents decreased. The number of military settlers from the end of 1946 to 1949 hovered at around 1,000 people, and together with their families they numbered approximately 3,000-3,500 people. While a year after the end of the war the average family consisted of 2.9 people, in 1949 it was 3.6 people. This growth was undoubtedly influenced by the increasing number of births.

\section{Ludność powiatu gubińskiegow świetle sprawozdań sytuacyjno-statystycznych z lat 1945-1949}

\section{Streszczenie}

Artykuł powstał na podstawie powojennych sprawozdań i raportów starosty oraz oddziału Państwowego Urzędu Repatriacyjnego w Gubinie. Opisano proces wysiedlania ludności niemieckiej, napływ osadników wojskowych, repatriantów i przesiedleńców oraz strukturę tej ludności według płci, wieku i miejsca pochodzenia. W czerwcu 1945 roku rozpoczęto wysiedlanie Niemców z powiatu, deportowano około 12 tys. dawnych mieszkańców, ale w kolejnych kilku miesiącach do powiatu została przywieziona lub przybyła pieszo ludność niemiecka z kierunku wschodniego. Ze względu na czasowe zamykanie granicy oraz brak transportu (szczególnie zimą) liczba ich w powiecie rosła. Na początku 1946 roku zliczono 574 Niemców, w sierpniu 682, a w październiku 739. 30 maja 1947 roku wywieziono większość Niemców, 31 maja zliczono ich 134, w lipcu 34, a na początku 1948 roku tylko 3 osoby. Od połowy 1948 roku do marca 1949 roku nie było w powiecie ludności niemieckiej. W kwietniu 1949 roku w Gubinie było 3 Niemców, a od lipca 2. Stan ten utrzymał się do końca roku.

Napływ ludności w latach 1945-1949 był niezadowalający i nie udało się odbudować przedwojennego potencjału ludnościowego. W 1939 roku wschodnią część powiatu gubińskiego, która w 1945 roku przypadła Polsce, zamieszkiwało 44 tys. mieszkańców, a w sierpniu 1945 roku powiat liczył zaledwie 3,5 tys. i w styczniu 1946 roku 4,8 tys. mieszkańców. Liczba ta na skutek napływu ludności zwiększyła się pod koniec 1946 
roku do 12 tys., a pod koniec 1949 roku tylko do 13,1 tys. mieszkańców. Nieznaczny wzrost zaludnienia w ciągu tych 3 lat sugerowałby spadek napływu ludności, ale napływ, choć coraz słabszy, trwał, jednak dotychczasowi osiedleńcy opuszczali nieprzyjazny ich zdaniem powiat. Wskazywano na słabość ziem, brak komunikacji, inwentarza i miejsc pracy, a także na obawy związane z bliskością granicy z Niemcami. Obszar ten był także nawiedzany co roku klęskami naturalnymi (gradobicie, powodzie, susza, plaga myszy $\mathrm{i}$ ostu), co potęgowało istniejące problemy związane $\mathrm{z}$ aprowizacją.

Powiat był w analizowanym okresie najmniej licznym i najsłabiej zaludnionym powiatem Ziemi Lubuskiej. Ogółem liczba osiedlonych osób od sierpnia 1945 do końca 1949 roku wzrosła ponad 3-krotnie (340\%), miasta Gubina o zaledwie 42\%, a wsi 12-krotnie. Największy przyrost ludności obserwowano do końca 1946 roku - wzrost liczby mieszkańców powiatu był 3-krotny. Doszło do kilku znacznych ubytków ludności: jesienią 1946 roku, wiosną i jesienią następnego roku oraz jesienią 1948 roku. Pod koniec 1945 roku połowa mieszkańców powiatu zamieszkiwała miasto, ale w kolejnych latach ludność osiedlała się głównie na wsi i tym samym w końcu 1949 roku mieszkańcy wsi stanowili już 66\% zaludnienia. Powiat na tle województwa i całego kraju charakteryzował się stosunkowo niskim wskaźnikiem feminizacji (108 K/100M). W Gubinie dominowała ludność przesiedlona z centralnej Polski (ok. 70\% mieszkańców), a na wsi repatrianci (również ok. 70\%). Duży odsetek mieszkańców to osadnicy wojskowi i ich rodziny (25-30\%). Na początku 1946 roku stanowili oni ponad połowę mieszkańców powiatu, ale w kolejnych latach udział tej społeczności w ogólnej liczbie mieszkańców zmalał. Liczba osadników wojskowych od końca 1946 roku do 1949 wahała się w granicach 1000 osób (z rodzinami liczyli łącznie ok. 3-3,5 tys. osób). Rok po zakończeniu wojny przeciętna rodzina liczyła 2,9 osób, a w 1949 roku już 3,6 osób. Na wzrost ten niewątpliwie wpłynęła zwiększająca się liczba urodzeń. 